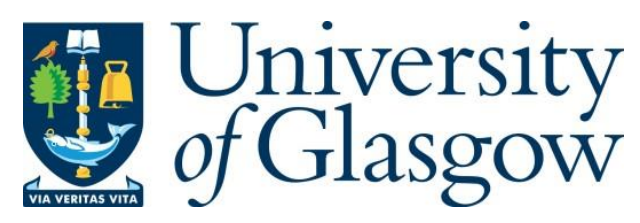

Botterill, K., Hopkins, P. and Sanghera, G. (2020) Familial geopolitics and ontological security: intergenerational relations, migration and minority youth (in)securities in Scotland. Geopolitics, 25(5), pp. 1138-1163.

There may be differences between this version and the published version. You are advised to consult the publisher's version if you wish to cite from it.

http://eprints.gla.ac.uk/171596/

Deposited on: 19 October 2018

Enlighten - Research publications by members of the University of Glasgow http://eprints.gla.ac.uk 


\section{Familial geopolitics and ontological security: intergenerational relations, migration and minority youth (in)securities in Scotland}

\section{Abstract}

This paper discusses the family as a site of geopolitics. Bridging scholarship in feminist geopolitics, political psychology and sociology, we explore the psycho-social dynamics of family life and theorise the family as a multi-scalar, relational site of security. Original data collected with ethnic and religious minority youth in Scotland is presented alongside an analysis of how family relations, at interconnected scales, mitigate against and/or re-inscribe broad geopolitical narratives of security. We employ the concept of ontological security (OS) to analyse the role of the family, and the relationships within it, on shaping youth securities. We discuss 1) how family histories and intergenerational experience shape young people's sense of security; 2) how young people negotiate and resist family norms and values that reproduce securitizing geopolitical narratives; 3 ) how young people find security when family is absent or indeterminate. In each case, we analyse how geopolitics operates through family life. The paper makes two key contributions: first, we use original empirical data to theorise ethnic and religious minority youth securities; second, we show the value of OS as a conceptual tool for understanding psycho-social dimensions of familial geopolitics.

Keywords: family, youth, ethnicity, feminist geopolitics, ontological security

\section{Introduction}

The domestic realm tends to be seen as distant and separate from the international. In classical geopolitics and realist IR the domestic politics of the region or state is theorized as distinct from international politics. Such binary thinking is disrupted by feminist scholars of geopolitics and IR for whom the domestic, everyday and intimate scales of security are intertwined with the international (Cowen and Story, 2013; Dowler and Sharp, 2001; Hyndman, 2004; Pain and Staeheli, 2014). From this perspective, geopolitics is not defined as macro-scale political discourse and action that impacts on intimate, embodied and emotional life, rather the two are co-constituted and entangled (Pain 2009). This is illustrated through analyses of the home and family as domestic sites of geopolitics (Brickell, 2012; Harker, 2012; Pain, 2009). Moreover, emerging work on 'geo-social' aspects of international politics have emphasised the role of social relations in constituting security - the 'experiences, practices, subjects and topographies' of security (Hörschelmann and Reich, 2017:73).

This is the pre-proofed 'accepted' version of the paper now published in Geopolitics. 
In this paper, we employ a feminist geopolitics framework to explore the ways in which the family acts as a site of geopolitics. We advance the concept of ontological security as a tool to explore how family histories and relations shape young people's sense of stability and continuity. Families are entangled webs of social relations that are co-constituted and dynamic; they are the social site of conflict, diplomacy and security - they are a political form of life. We make two key arguments in this paper that contribute to understanding the family as a site of geopolitical (in)security.

First, we argue that intergenerational relations of the family are central to young people's sense of security. Young people view the family both as a site of political control where patriarchy and racialisation operate, and as a space of resistance where political inequalities are negotiated and disputed. Many of the intergenerational relationships we explore are situated within a context of postcolonial and/or forced migration that frame family life and generational expectation. Such histories of conflict and struggle are a burden to many second- and third-generation young people whose modern, individualized aspirations feel distant from 'communal discourses' (Nagar, 1998) of faith and heritage. We discuss how young people's critique of their parents' generation shows political agency and cuts through patriarchal and racialized structures in an appeal to more peaceful engagements with difference. At the same time, parental experience of racism, violence and trauma generate a strong sense of justice among young people and a commitment to political engagement. As such, family relationships contribute to young people's OS, equipping them to contest and cope with current discourses of national security that script ethnic and religious minority youth as threatening subjects through the securitization of migration (Bigo, 2002; Ehrkamp, 2016).

Second, we demonstrate the conceptual value of OS to feminist geopolitics of security. Here, we refer to OS in the context of family life and how young people's sense of security is (in)validated in and through the family. Following Laing (1960), we argue that OS is a relational concept in that to be ontologically secure requires the recognition and validation of others. The concept contributes to feminist analyses of security because it enables a multi-scalar and relational analysis of interconnected geopolitical and social securities alongside the psycho-social experience. Through this lens, we foreground the intimate and personal experience of security and consider how, combined, these might contest the more un-human and depersonalized interpretations of geopolitics (cf. Hyndman, 2001; Koopman, 2011; Pain and Staeheli, 2014; Sharp, 2013;)

This is the pre-proofed 'accepted' version of the paper now published in Geopolitics. 


\section{Intimacy, emotion and the geopolitics of feeling}

Challenging the hegemonic and 'masculinist' scripting of geopolitics, feminist scholars have examined the everyday, intimate, emotional and embodied experiences of geopolitical actors often neglected in conventional accounts (Askins, 2014; Cowen and Story, 2013; Dowler and Sharp, 2001; Enloe, 1990; Hyndman, 2004; Pain and Staeheli, 2014; Pain and Smith, 2008; Smith, 2012). In these accounts, geopolitics is embedded in everyday life and everyday life is geopolitical. For example, in work on the geopolitics of fear, Pain (2009) has convincingly argued for an emotional geopolitics of fear that challenges the "hierarchical, procedural scaling of emotions' often present in analyses of the war on terror. She argues that unreflexive assumptions about how emotions impact upon a passive general public should be challenged by analyzing the ways in which emotional and intimate lives contest 'big' scale geopolitics through 'resistance, agency and action' (Pain, 2009). Pain and Staeheli's (2014:346) notion of intimacy-geopolitics, by definition, connotes the 'inseparability of politics from emotional geography'. Intimacy, they argue is 'not simply the terrain on which broader sets of power relations are written. It is already out there, quietly working to produce domination as well as resistance across all practices and sites' (ibid.:346). In urban geopolitics too, scholars have contested 'unemotional' and 'technocratic' perspectives to explore the emotional and affective 'atmospheres' of urban conflict and security (Fregonese, 2017; Laketa, 2016). Laketa (2016) draws on the work of Ahmed to explore how the geopolitics of bordering is materialized through different affective intensities. Laketa points to the tension between geopolitics of emotion and affect showing the tendency to consider either the 'popular' discourse produced through media representation or the 'visceral' experience and narratives of marginalized actors. She argues that feelings are politically relevant because they help us to understand dynamics of power and can provoke resistance and analyzing them may be part of a broader challenge to hegemonies.

Feminist political geographers, along with critical IR theorists, have also been at the forefront in re-theorizing security (Williams and Massaro, 2013). Countering state-centric approaches to security advanced by classical geopolitics and realist IR, scholars have called for a 'finer scale of security' that 'traverse public/private distinctions' (Hyndman, 2001:219). In these accounts, alternative and often 'unexpected' sites and scales of security are foregrounded which recognise relationality and multiscalarity (Koopman, 2011; Secor, 2001, Sharp, 2013;

This is the pre-proofed 'accepted' version of the paper now published in Geopolitics. 
Williams and Massaro, 2013) ${ }^{1}$. Notably, in the field of youth geopolitics, children and young people are not read as merely the subjects of geopolitical representation and action, but are political agents that shape geopolitics in their own right (e.g. Benwell and Hopkins, 2016). The focus on children in geopolitics and IR has often in been in terms of how they potentially impact on the security of a state and society as child soldiers, extremists, terrorists or child labourers. The role that children play in international politics is frequently under-theorised, in part, because traditional IR theories do not recognize children as autonomous political actors (see: Beier 2015; Watson 2006). Countering this trend, young people's explanations and perspectives of security in family life are at the centre of this paper, contributing to scholarship on youth geopolitics.

\section{Understanding family as a site of security}

There has been widespread interdisciplinary interest in the geographies on intimacy and personal lives outside feminist geopolitics. Those working to understand the economic and social geography of the household (Pratt, 2012); intergenerational relations (Vanderbeck, 2007; Richardson, 2015; Hopkins et al, 2011); youth transitions (Cieslik and Pollock, 2002; Hopkins et al, 2015;) and education (Holloway et al., 2010). Yet, research on the family has been, as Valentine (2008) has argued, a 'peculiar absent-presence' in geography. Critical sociologists have stressed the continuing salience of the family as a socio-spatial formation contesting generalizing theories of modernity that point to its decline (Finch and Mason, 1993; Jamieson, 1998; Morgan, 2015; Valentine, 2008). These accounts move beyond the family as a social institution and focus on diverse, uneven family practices and relationships of intimacy and care (Williams, 2004). In mapping the terrain of family studies in geography, Valentine (2008) advances a 'new geography of intimacy' that explores how diverse intimate relationships and affective relations co-constitute the global economy through innovative empirical methodologies. Thus, recasting intimate life as geoeconomic and multi-scalar, and demonstrating the significance of the family in understanding social and economic change. What role, then is there for critical and feminist geopolitics?

Perhaps because the family has predominantly been theorised sociologically - both as a discursive product and material reality, there are fewer critical engagements in geography. Or, as Harker (2012:849) suggests, families are often framed as 'politically conservative', patriarchal, heteronormative and exclusionary and are thus often considered an outmoded

\footnotetext{
1 for similar work in critical security studies see Booth, 2007; Bourne, 2014; Enloe, 1989; Neocleous, 2008; Shepherd, 2013; Wibben; 2011
}

This is the pre-proofed 'accepted' version of the paper now published in Geopolitics. 
and regressive social form by critical theorists. Following this, we believe that understanding families as sites of geopolitics is vital to theorizing socio-political change. This idea maps onto what Mitchell and Kallio (2017:8) refer to as the 'geosocial': an approach to connect the realms of politics to social and economic actors, practices and networks that are also geopolitical. They argue that 'the intertwining of geopolitical agendas and everyday social relations enables us to see sites of resistance, as well as the production and negotiation of vulnerability, for example, in new forms of gendering and racialisation occurring worldwide on an ongoing basis' (ibid.). This is a valuable approach for analysing security across multiple scales. As Hörschelmann and Reich (2017:80) contend:

'Social relations and the emotional and practical work invested into them are shown to be a key connective tissue through which entanglements of different (in)securities are co-produced. A less territorialised mapping of the socio-spatial topographies of (in)security, is required too, however, to capture both the relational character of the social and the possibility that security may rest less in the stability of social relations than with the possibility of shaping, transforming and, sometimes, leaving them'

The geosocial offers a way to domesticate geopolitics and explore relationships of emotion and affect that characterise global relations and transnational identities. By understanding how the geopolitical and the geosocial interact we can deepen our understanding of how geopolitics is 'domesticated'. Potentially then, the geosocial extends ideas of emotional and intimate geopolitics to incorporate social relations and structures of feeling.

To some extent analyses of the geopolitics of home and family are already doing this. As Hörschelmann (2008:601-2) has argued the home is 'a key site through which the macroscale is realised and experienced in everyday life' (also see Blunt and Dowling 2006; Caluya 2010). Brickell's (2012) intervention to advance a 'geopolitics of home' sought to problematize further the conceptual boundary between public and private. She shifts focus from the effects of geopolitics on the home, through the effects of warfare and 'domicide' (Porteous and Smith, 2001), to exploring the role of the home in the production of geopolitics. This framing moves beyond seeing the home as a space affected by geopolitics, or an object of geopolitics, toward an understanding of how the home does geopolitics (Brickell, 2012). Similarly, Harker's (2012) research on family and geopolitics in Palestine demonstrates that the family is both a 'discursive object' produced through histories of colonisation and modernisation, and a complex and fragmented set of practices that are also resistant and demonstrate agency. Harker (2012: 850) critiques the discursive production of the family in geopolitics and argues for 'a geographical approach to family which takes account of ...multiple, contingent relations between family spacings, politics, and ethics'. This is the pre-proofed 'accepted' version of the paper now published in Geopolitics. 
Indeed, the call in feminist geopolitics to connect the personal and everyday with the international and exceptional speaks to developments in family studies of analysing 'the intersections of the private and the public, the intimate and the politics, the interpersonal and the structural' (Mason, 2015: 19).

\section{Family life and psycho-social securities}

To explore the family as a social site of geopolitics we must also interrogate the (in)stability of its relationships and the psycho-social processes that shape family life. How do intergenerational relationships shape the understanding and practice of geopolitics? What role do different actors play in securing or securitizing the lives of relatives? How are family values geopolitical and what impact might these have on the individuals within? Feminist geopolitics is well placed to answer these questions through the focus on intimate and emotional registers and transmissions. Our contribution to these debates is to mobilize the concept of ontological security (OS) as a lens to explore the psycho-social processes involved in familial geopolitics. In previous work, we have used this concept to understand how global discourses of security shape everyday, relational practices of security, and subsequently work to produce psycho-social insecurities among and between individuals (authors, 2016; 2017). We have argued that for ethnic and religious minority youth in the UK the combination of racism, Islamophobia and economic insecurity has the potential to produce ontological insecurity - 'the anxious 'being in the world'. Racism and Islamophobia, we argue, operate as a threat 'to the core of personhood and validation that one belongs in a particular place, and can function equally' (authors, 2016:8). In this paper, we highlight the conceptual value of OS as a tool to examine the interconnected 'geosocial' and geopolitical processes that operate in and through the family.

The concept of OS is derived from the Scottish psychoanalyst R.D. Laing, whose work on agoraphobia and schizophrenia led to the development of a theory of security for the individual. He proposed that to be ontologically insecure is to experience the 'ordinary circumstances of life' as a 'continual and deadly threat' (Laing, 1960:42). In sociology and international relations too, the concept has been re-worked at a range of geographical scales to express the process of insecurity for individuals, groups and states (Giddens, 1991; Kinnvall, 2004; Steele, 2008). While there is not space for a full discussion on the theoretical trajectories of OS here (see authors, 2016; 2017), it is useful to emphasise how Laing saw the role of family in facilitating OS. The family is viewed as a key site of meaning with family relationships as central to an individual feeling real or unreal, under threat or safe (McGeachan, 2014). Laing (1969:1) is concerned with 'the texture of the actual lived This is the pre-proofed 'accepted' version of the paper now published in Geopolitics. 
experience of people in families', the 'social product' that is fabricated through intergenerational relationships, behaviours and interactions - whether known or unknown. This framework raises questions for geopolitics- what constitutes a real family and how is this governed, protected, represented and lived at different scales? How is trust built within and between families and what impact does familial trust or mistrust have on local and national geopolitical scenarios?

We find OS a valuable concept for feminist geopolitics for two reasons. First, it 're-scales' geopolitics and acknowledges the interdependencies between political and 'social' securities (global, national, local) alongside the individual bodily and 'psycho-social' experience. This enables an understanding of social context alongside psychological registers that shape human security, connecting the geo-social with intimacy-geopolitics. We argue that OS has the potential to be a platform from which to explain and explore the links between family and geopolitics - whether this be about the family offering ontological security in insecure times, or whether the family (or someone in it) is ontologically insecure as a result of geopolitical events. Second, it moves beyond the individual or family as bounded units of geopolitical analysis and encourages a deeper, psycho-social engagement with entangled relations within and between (cf. Hörschelmann and Reich, 2017). Methodologically, we suggest that a focus on the personal narratives of young people is necessary for understanding how individuals represent themselves in relation to others as secure or insecure beings. Through this we can explore how geopolitics is felt intimately and relationally at a range of scales and how this affects personhood and a secure sense of being in the world. As such, looking at the domestication of geopolitics through OS enables an appreciation of the felt, personal, and psycho-social ways that geopolitics is experienced on the body, with the family, at home and how it connects to broader geopolitics structures and discourses.

In the following sections, we employ OS to understand how resources within the home and family are used or discarded in the quest for personal security. Firstly, we discuss the intergenerational securities demonstrating how the family is a location that nurtures political engagement and resilience against micro-aggressions in public space. Secondly, we discuss the family as negotiation and resolution, particularly focusing on how young people negotiate 'protections' or compliance with assimilationist models of citizenship. Finally, we discuss the absence of family networks for unaccompanied asylum seekers and how insecurity is negotiated when family is temporarily or permanently missing due to displacement as a result of war and conflict.

This is the pre-proofed 'accepted' version of the paper now published in Geopolitics. 


\section{Researching youth insecurities}

This paper is based on an AHRC study of young people's everyday geopolitics in Scotland, involving focus groups and interviews with ethnic and religious minority young people across rural, suburban and urban Scotland $(n=286)$. The research took place surrounding the 2014 Scottish Independence Referendum and explored topics on youth political participation, everyday geopolitics, racism and Islamophobia. A wide range of young people aged 12-25 participated in the study, including Muslims, Sikhs, Hindus, non-religious ethnic minorities, international students and refugees. This paper is based on those with self-identified ethnic minority heritage in order to explore particular experiences of ethnic and religious minority family lives. Participants were accessed through schools, colleges and universities as well as community and voluntary organisations.

There are a range of complex ethical issues involved in researching young people and in particular, in conducting research with marginalized young people. We were very attentive to the issue of informed consent, especially in the context of schools where young people may feel compelled to participate through pressure from teachers or other authority figures. We therefore took the time to explain the aims of the project (all participants with an information leaflet) and to discuss issues such as confidentiality and anonymity. We received full institutional ethics clearance prior to commencing the research and remained attentive to ethical issues throughout the project. All members of the research team also completed enhanced criminal records clearances with Disclosure Scotland (an executive agency within the Scottish Government).

All data were fully transcribed, coded using NVivo and the analysis for this paper is drawn from and in-depth interrogation of the coded data about: 'family', 'intergenerational relations' and 'security' (economic, political, social, ontological). This in-depth narrative analysis enables us to demonstrate the complex negotiations of family life in particular communities, and for particular individuals. Throughout the research process - including during the analysis - we paid close attention to our positionalities as 'adult' researchers whom in many respects were very much 'outside' in relation to the identities of our participants. Despite these differences, our diverse connections - whether this be through similarities in relation to accent, ethnicity or political interests - coupled with our experience and training as youth researchers, enabled us to sensitively and ethically engage with our participants about their lived experiences. As such, we are neither complete outsiders nor insiders when it comes to the focus of this research.

This is the pre-proofed 'accepted' version of the paper now published in Geopolitics. 


\section{Intergenerational securities}

For many of our interviewees, the family home was a site that provided the foundations for a secure life. Perceptions of a secure life, however, differed depending on context and many young people spoke about security in relation to intergenerational experiences of migration, racism and violence. Maalik is an Ahmadiyyan refugee living in a small town in Central Scotland with his parents and grandmother. His mother migrated from Pakistan with Maalik, his grandmother and younger brother to seek refuge in Scotland from the 'hate' he says they experienced in Pakistan as minority Ahmadiyyan Muslims. They have been living in Scotland for 6 years and have been granted indefinite leave to remain².

"I guess they moved here because of me, they wanted a better future for me...my mother came from a really poor background where there were like 7 siblings and in Pakistan...So I guess when she was growing up she was probably thinking, 'I don't want my children going through this' you know, 'we're barely able to eat breakfast', ... I personally think in contrast to my parents, I...we're completely privileged you know...Yeah, she wanted us to be having a better life than her" (Maalik, male, Pakistani refugee, 16-18, Central Scotland).

Maalik refers mostly to his mother's experience of life in Pakistan to explain the motivation for seeking asylum as a move away from poverty to relative privilege in Scotland. Maalik's own sense of security is formed in relation to his parents' experience of economic and political insecurity. He recalls the process of asylum as 'interrogation' despite being a young child when his family arrived in the UK: 'my mother was obviously getting interrogated, she couldn't speak, she doesn't speak English'. Maalik's description of the journey through asylum demonstrates an awareness of the relative peace and security he feels in Scotland again compared with his mother's journey as a securitized subject. He says 'in Scotland, it's all calm and quiet...it's just homely for me', his sense of security reflected in affective sensations away from the turbulent noise of the migration journey. Maalik and his family are not involved in mainstream Muslim faith practices, but are part of a small community of Ahmadiyyan families in Scotland. The intra-family connection is a source of both continuity and freedom to practice faith that had previously been denied. However, he is affected by the everyday frictions between different Muslim communities in Scotland:

\footnotetext{
2 'Indefinite Leave to Remain' is an immigration status granted by the UK Home Office meaning an individual has permission to stay in the UK permanently. Scotland is under UK jurisdiction for immigration and asylum and is required to comply with UK Home Office rules. However, the Scottish Government is responsible for devolved matters such as access to healthcare, education and strategies for integration of immigrants, refugees and asylum seekers (see New Scots Refugee Integration Strategy, Scottish Government, 2017)
}

This is the pre-proofed 'accepted' version of the paper now published in Geopolitics. 
"It's the confliction between Ahmadiyya Muslims and Sunni Muslims, Shia Muslims and all the other sects in Islam. It's just I've been led to believe well I've seen what happens... if you say that 'I'm an Ahmadiyya Muslim' to a Sunni Muslims or a Shia Muslim they don't particularly take it easy, they go shouting abuse"

Maalik only has one (Sunni) Muslim friend and says that they understand each other with a caveat of 'if his father knew maybe it would turn out different and he'd probably act up'. The safety and refuge secured by Maalik's mother for their family in Scotland, and the intra-family networks of support locally and nationally, is compounded by a compliance with, often gendered, communal discourses of faith at school and in the home. Furthermore, while Maalik says he has adjusted well to Scotland and racism is 'not a major problem', during the interview he referred to instances of verbal racism against him instigated by white Scottish people. He explained ambivalently that white Scottish people 'don't completely understand, like, Muslims to the extent that they're happy of letting them, you know tolerate them and accept them into their communities'. These examples show that home and community is not a 'sanctuary divorced from wider power geometries' (Brickell, 2012:586) but is imbricated in the geopolitics of gender, ethnicity and faith.

The political security gained through asylum was referred to by some young people as a springboard to political participation in Scotland. Celia is a Kurdish refugee who identifies strongly with Glasgow, Scotland, and the Scottish National Party. She talks here about her family's experience of displacement, torture and migration in a discussion about her interest in politics:

"I think my family played a big part as well in my life. My family have always been involved in politics... my dad, my uncle; my uncle was prisoner at Abu Ghraib for 14 years...he was tortured and all for his being against the Saddam regime...But like my dad, also his father and two brothers were executed, and my family's always been very involved in politics and standing up for people's rights and that a dictatorship regime should not oppress the people and people have the right of their own choosing and be democratic" (Celia, female, Kurdish refugee, 22-25, Glasgow)

Celia's frank discussion of her father's experience reveals the impact of prior contexts of violence on her present interest in global social justice. Celia is active in campaigning for political causes having set up a Kurdish youth cultural community in her locality and campaigns for the rights of asylum seekers. Her political engagements have been shaped by This is the pre-proofed 'accepted' version of the paper now published in Geopolitics. 
her parents, actions that she says make her 'realise that...my voice has meaning, someone will listen to it'. There is both a gratitude and a purpose derived through intergenerational experiences of trauma in Celia's narrative. She has a vision for social and political change, shaped by the injustice of her father's experience of torture, and the broader political discourses that oppress and target communities.

"So, I like to also inspire young generation to follow the same path and make a difference, your voice can be, is valued and you're no different from other ones and things like that, I think. I like to help other people and I think I always had that in me, I like to help other people. So, I do feel like I have belonging here and have security as well without the oppression"

In both these examples ontological security is found in the relative safety and privilege experienced by young people compared with their parents. However, the residues of intergenerational trauma are felt emotionally and subsequently actioned, particularly in the case of Celia, to challenge injustice. As Ahmed suggests histories are 'bound up with emotions... it is a question of what sticks, or what connections are lived as the most intense or intimate, as being closer to the skin' (Cited in Laketa, 2016:666). Furthermore, security is discussed not at the scale of the family home, but of the city or nation to which their families have come. For both Maalik and Celia, Scotland is a secure home when understood in the context of the families' migration and asylum journeys making it a site of relational geopolitics.

Many of those interviewed cited transnational loyalties to places of parental heritage or, in the context of international migrants, students and refugees, their home states. Linked to this, transnational faith practices and identities were performed by some of the young religious minorities interviewed. Here, the meaning of family was extended and understood through faith. Ramanjit is a Scottish Sikh who has grown up in Glasgow, he talks about the global challenges affecting local Sikh families in Scotland:

"So, you know, when global issues have happened, like 9/11 for example, and how governments have dealt with that, and the knock-on effect on, on Sikhs or Muslims, or other communities, and how that's affected them in their day to day life....but I very much doubt there is anybody sitting in Whitehall thinking how is this gonna impact somebody in their day to day life. They're not thinking that at all. You know, so that presents a lot of challenges for individuals and families, but again it brings the onus

This is the pre-proofed 'accepted' version of the paper now published in Geopolitics. 
on the family to try and deal with it with no tools and no support and no recognition..." (Ramanjit, male, Sikh, 22-25, Glasgow)

Ramanjit extends the scale of the family to a faith community in multiple locations. He then goes on to talk about the politics of misrecognition (authors, 2017), and the attacks on Sikhs in the aftermath of $9 / 11$. In the extract below he refers to the Sikh 'family' response to the murder of Balbir Singh Sodhi, an American Sikh who was among the first victims of misrecognition following $9 / 11$ in the United States.

'I think it's a very Sikh way of thinking as well, you know, like when that one incident happened, you know, we very much, we just tried to deal with it...we supported the family, I say we... the Sikh nation. But Sikhs in America, you know, they supported the Sikh family and there was guidance and support there, but they went and dealt with issues so they created new organisations like the Sikh Coalition.. they worked their way straight into the Whitehouse and, and every step of the way was purely through education and dialogue."

Once again, racism against Sikhs is felt across borders and motivates transnational acts of solidarity and resistance. Much of the scholarship on transnationalism argues that transnational affiliations and mobilities decline over time, particularly among second generation youth (Levitt and Waters, 2002; Werbner, 2005). However, Reynolds and Zontini (2016) argue that transnationalism is symbolically and materially significant for second and third generation minority young people for whom new meanings of homeland and heritage are hybrid and operate at different scales. In our example, faith plays a key role in nurturing transnational solidarities among second and third generation young people against racial injustice (cf. Singh, 2015). Here, young people's ontological security is achieved through transnational solidarity and community, what Vertovec (2004:17) calls the 'transnational moral economy of kin'. For Ramanjit, transnational kinship ties are energetic networks of political resistance, he refers to family as the site of 'guidance and support' providing the tools to cope with the 'day to day' impacts of geopolitical trauma. Geopolitics unites and creates linkages across borders and scales. People seek security at times in/through the extended family; transnationalism has facilitated this and helps to mitigate hardships encountered by young people.

\section{Family as negotiation and resolution}

This is the pre-proofed 'accepted' version of the paper now published in Geopolitics. 
Recognising that young people contest, resist and disobey the expectations and rules of the family is by no means a new idea (Dwyer, 2000; Ehrkamp, 2013; Katz, 2004). Hörschelmann and Reich (2017) argue that stable social relations are not a precursor to individual security, rather that security is often sought through contesting and transforming social norms. We focus here on data showing how the negotiation of familial expectations is also a negotiation of geopolitics. First, we discuss the intra-communal tensions and conflicts that cut across generations of families and discuss how young people negotiate these in the context of being a 'modern individual'. Then we focus on the gendered and embodied negotiations of young people in relation to parental expressions of compliance and protection. Nagar (1998) argues that 'communal discourses' defined around religion, caste or race construct hierarchies and social boundaries within groups. The following extracts from two young Sikhs show how they negotiate 'communal discourses' within the communities they participate in.

"Older generations here had [caste politics], and it will maybe trickle down. The only thing is that, you know, because it's all family based ... they have their parents who are involved in that community, and involved in that specific Gurdwara will naturally be drawn to that. As an outsider I could enjoy all the programmes, and I stayed out of it... I was very lucky because people didn't know really who I was, but knew me, knew my name, knew, kind of, my family, but there was no family politics that I was affiliated with this place or that place" (Darvesh, Sikh, male, 22-25, Aberdeen)

Darvesh narrates the communal politics of the Gurdwara as an 'outsider', positioning himself on the periphery of complex family politics, hierarchy and conflict. Darvesh grew up in Glasgow but has lived in different parts of Scotland and now feels 'at home' in Aberdeen. As such he doesn't affiliate with a particular 'place', but rather is an individual with flexible, deterritorialised connections to faith communities in the city. Such communal discourses then require a territorial attachment, a place in which social boundaries can be marked. However, they are also subject to 'contestation, negotiation and modification' (Nagar, 1998:136). Gundeep, a Sikh female living in Glasgow reflects:

"The Sikh community I would say they are amazing...But if, I'll have to be honest in terms of Glasgow I believe personally... it's very segregated in terms of caste...I don't believe in the caste system. I mean if you're proud of who you are, and if you're proud of your caste then that's fine, keep it at that. But for you to go and, like, not bully, but for you to go and, like, slate other people because of who they are I

This is the pre-proofed 'accepted' version of the paper now published in Geopolitics. 
don't think that's right at all. No, I personally think our generation is trying to... simmer it down" (Gundeep, Sikh, female, 22-25, Glasgow)

These extracts highlight generational differences amongst Sikh communities in different Scottish cities. This contrasts literature that frames 'Asian' families as cohesive units that facilitate community engagement (Thaiper-Bjorkert and Sanghera, 2010). There are political histories that have shaped experiences of first generation South Asians in the UK and young people's sense of community belonging in diverse ways. Both Darvesh and Gundeep celebrate the value of community events and celebrations to nurture a sense of belonging among Sikhs in the city. However, they do not perform community as an overt political strategy, extricating themselves from the frictions of caste politics among some South Asian families. Arguably, young people have new geopolitical challenges to negotiate which concurrently affect their role within the 'Asian' family. These differences do not, however, reflect a disengagement with family networks or suggest the family is in decline as a mode of cohesion and security as posited by some (see Beck and Beck Gernsheim, 2002). Rather, young people's sense of self is understood in relation to intergenerational conflict and negotiated through peaceful everyday practices (Ehrkamp, 2013).

As discussed, many young people explained generational difference with reference to migration histories and there was an awareness of the challenges faced by previous generations as 'new migrants'. Often when young people talked about experiences of racism they spoke in relation to their parents' prior experiences. We have discussed elsewhere the way in which racism and Islamophobia against young people has the potential to produce a profound sense of ontological insecurity (authors, 2017). In the following extracts, we explore how our interviewees positioned themselves in relation to other family members to mitigate against such insecurities. Here, Jamal suggests that racism was much worse for first generation Asian migrants than for the current generation of ethnic and religious minority young people in the UK.

"it's much more controlled the [racism]... the older generation might have been through a lot more. A' think they, these generations are pretty much a bit, okay abroad there's much more abusive and more violent. But a' think in terms of being in the UK it's, we don't receive that much like anger or abusive language or any criticism, or any more than in the olden times" (Jamal, male, Muslim, 19-21, Glasgow)

The comparative assessment Jamal makes about racism in the UK as worse for his parents This is the pre-proofed 'accepted' version of the paper now published in Geopolitics. 
minimizes his own experiences of racism and is strategy of self-securitization. Others explained this relative security with individualised narratives positioning themselves as 'modern', 'established', socially mobile individuals who are not so 'different' from other white Scottish young people.

"The last generation of men most of them became shop owners... they sort of got on with it themselves. But now we are sort of established here ...we are working up like every other young person here and we are going through the qualifications, going to the interview stage. And we are finding we have to prove ourselves a little bit more because.... lot of the Pakistani's didn't know English a lot, so we get stereotyped a lot. ...I don't associate myself with a sort of culture because half my family is from Pakistan, half my family is from here...I just get a bit confused when people associate me with my culture because I am like...that is not who I am" (FG Muslim focus group, male, East Renfrewshire)

This extract reveals that whilst social and cultural capital for South Asian minorities in Scotland may be changing there are structural barriers that continue to shape young people's aspirations and outcomes. Thaiper-Bjorkert and Sanghera (2010:251) argue, whilst traditionally the 'South Asian' family has often been constructed as unified corporate units, the reality is that they are in fact 'sites of complex negotiation and contestation of traditional patriarchal norms'. Young people seem less connected to the traditional 'incorporation' processes of first generation South Asian migrants, they are embedded in flexible labour markets and are negotiating hyphenated identities (Din, 2016). However, as this extract shows, young people are not unaffected by long-standing cultural stereotypes and processes of racialization that require young Pakistani's in Scotland to 'prove' themselves. The structural racism in the labour market is deflected as quickly as it is acknowledged by this participant as he rejects cultural associations that may dampen his individual aspirations and sense of worth.

Familial norms and expectations are a source of stability and continuity for young people, often in contrast to geopolitical threats external to the family. Sanghera and Thaiper-Bjorkert (2017: 91-92) have argued that the lives of young Pakistani Muslim men and women 'are conditioned in terms of expectations (e.g. work, education, marriage and life course), moral economy of kin (e.g. providing support and guidance to kin based on trust and reciprocity), and institutional structure (e.g. how to organise or participate in religious/ethnic community and local associations). Significantly, it has meant that kin-based networks, relationships of trust and reciprocity are more easily sustained across space, whilst gendered, religious and This is the pre-proofed 'accepted' version of the paper now published in Geopolitics. 
cultural expectations, norms, values and practices are transmitted intergenerationally and may be an important source of security. But none of this is straightforward; rather it is open to inter-generational contestation, challenge and negotiation. We found that young people discussed how everyday mobilities, education, language and dress were all matters of familial administration, yet these were embedded in wider normative structures. When discussing intimate relationships with mothers, fathers, grandparents and siblings, young people revealed a complex dynamic that does not conform to the binary of traditional vs modern practices. Rani reflects here on her relationship with her mother and the awkwardness of language:

“...every time Parents Evening she'd have to come she'd always ask me 'oh get an interpreter for me', you know all those things. As a kid I would think 'oh, you know my mum can't speak English' this and that I would feel sometimes embarrassed about it. Even though now I feel silly like, 'why did I feel embarrassed' but I guess I did because she couldn't really, sometimes l'd feel like we can't mix in because of the language barrier." (Rani, Ahmadiyyan Muslim refugee, female, 19-21, Glasgow).

Rani is an Ahmadiyyan Muslim refugee and was granted indefinite leave to remain in 2008 . She talks about her embarrassment over her mother's English language abilities referring to a desire to integrate as an emotional process synchronised with a fear of exclusion or alienation. There is a sense of shame in not speaking English reflecting a discourse of citizenship and nationhood in which the English language is a 'cultural boundary marker' (Alexander et al., 2007:783). The logic of 'integration' and compliance to normative citizenship practices are not questioned. However, Rani 's irritation over familial barriers to integration dissipated as the interview progressed. She told the story of her forced migration, conveying compassion and admiration for her mother's courage during 'dawn raids' and more anger at the processing of asylum in the UK, demonstrating that intergenerational frictions wax and wane alongside everyday geopolitics, and are resolved in different timespaces. For Rani, the insecurities she feels about 'fitting in' are abated by the relative peace of her present situation showing how personal insecurity can be both intensified and reduced through family relationships, that are always connected to wider structural and discursive barriers to inclusion and wellbeing. When structural racism and exclusion is a shared familial experience, intergenerational relationships figure as important in providing a sense of continuity and a trustworthy source of support against broader uncertainties and inequalities (Giddens, 1991).

This is the pre-proofed 'accepted' version of the paper now published in Geopolitics. 
Many of the young people we interviewed discussed the gendered politics of the home related to mobility, dress and relationship choices. This came out most prominently in focus groups with Sikh and Hindu girls, as they debated 'overprotective' parenting and women's rights.

"I think girls are more protected than boys are...Like my parents are really over protective over me, compared to like my older brother..." (Hindu female, East Renfrewshire focus group)

"I think that the girls are like kept in more, but I think that is just normal for most people. Because my brother gets to stay out late all the time and I don't so..." (Kamala, female, Hindu, 16-18, East Ren)

For these young women the household is a gendered and constrained space. Moreover, the willingness to share these thoughts with the group and appear untroubled by it suggests that these young people expect parents to govern their choices to some extent, as Kamala reflects - 'I think that is just normal'. Given this, we do not essentialise their experiences as unfree or subjugated, but recognise the complexities of intergenerational relationships and expectations in young people's lives. Dress is also important here. The reasons why Muslim women decide to wear the veil (e.g. headscarf or hijab, full-face veil or niqab) have been well documented (e.g. Dwyer, 1999; Gokanksel, 2009; Secor, 2002). Much of this literature challenges simplistic accounts that associate veiling practices with the subjugation of Muslim women (Kapur, 2002). For many, the veil is considered an expression of empowerment and personhood (Abu-Lughob 2002), allowing Muslim women to negotiate public and private spaces (Sanghera and Thaiper-Bjorkert 2012) and resist assimilationist demands and Islamophobia (Kapur 2002: 218; Afshar et al. 2005). Our research found that parents often oppose the decision to veil, because they fear that their daughter will become more obvious targets of racism and discrimination. Tahali grew up in Dundee and her parents are from Bangladesh. She describes herself as a British Bengali Muslim and explains here her thoughts on religious dress.

"I think like I'm scared of what other people might say as well ... I have tried speaking to my mum...I asked her like would I be able to put it, like start wearing the hijab and she said that ... I'm still quite young and that I should grow up a bit and think about it. Cause once I put it on its best that you keep it on instead of taking it off and that just attracts more attention... people tend to talk about it as well... it kinda does the opposite what it's supposed to do" (Tahali, female, Muslim, 19-21, Dundee)

This is the pre-proofed 'accepted' version of the paper now published in Geopolitics. 
Tahali is apprehensive to wear the hijab because of the reactions of specific others - her family and friends. She talks about her mother's cautionary advice, and the potential impact on herself and her faith when strangers 'talk'. Her narrative is a negotiation of personal meanings of faith and the external threats of Islamophobia in public space demonstrating that the quest for OS is shaped by external and internal psycho-social meanings and embodied practices (cf. authors, 2017). Furthermore, these are relational, mediated by her mother who guides her decisions on faith practice and performance.

\section{Making family in-between securities}

We now discuss how young people negotiate security when family is absent or left behind. We explore how young people draw on extended family and friends to negotiate anxiety and fear in the context of intense geopolitical uncertainty. We focus on the experience of unaccompanied asylum seekers and refugees who travelled to Scotland without families and are supported by a range of social services and support networks such as those found in looked after and accommodated children's units, the social work system and in other voluntary organisations who provide services for refugee youth. In the case of many young unaccompanied asylum seekers, the journey to safety meant drawing on extra-familial networks and support. Fleeing conflict without family led to the formation of other relationships, negotiated in an emergency alongside circumstances of trauma and grief. There is an important body of work analysing the emotional and embodied experiences of refugee displacement and detention (Brun and Fábos, 2015; Conlan, 2011; Hyndman, 2010; Mountz et al., 2013; Vaughan-Williams, 2015). Hopkins and Hill (2008) discuss the pre-flight experiences and migration stories of unaccompanied children including the number who experience the death or persecution of their parents or other family members before their journeys to safer places. Some also fled persecution with groups of siblings with the oldest sibling taking on the role of head of the family (Hopkins and Hill, 2010). Much of the literature about unaccompanied minors understandably focuses on matters of social care provision, resilience, integration and belonging (e.g. Kohli, 2010). Ni Raghallaigh and Gilligan (2010) have pointed to the significant role that religious faith plays in facilitating unaccompanied minors' transitions to a new place by offering them a sense of comfort and everyday security.

Naz is a Somali Muslim male living in Glasgow. He left Somalia two years ago after his family were killed and he was given the choice to 'join [a militia] or be killed'. Here he talks about his family and his journey to the UK drawing on intermediary networks of faith and friendship at the boundaries of the family.

This is the pre-proofed 'accepted' version of the paper now published in Geopolitics. 
"I don't have any family... I don't know even other family where is. Because I know if I go back right now that definitely they kill me. ..the first thing, they look young people to join, like, in groups to kill other people. So if you don't accept that they kill you. ...I was, I was helping my father. My father was fisherman, so I was just helping fishing, like, we wash the fish and then, like, we get, like, small money. And the time I travel...my father was, like, he told me, like, he know he can't live for long life. And then he told me, like, anything happen, if I die... these things will help you in your future. So...the time all my family [was] killed that was that thing I take. And then I go to friend of my father... that man he help me to move to Somalia, to go Yemen. And I stay in Yemen, at Yemen I was stay in mosque, and then the guy who take me in the mosque I was helping, because the guy [had], like, a farm. Yeah, he have goat, sheep, something like that. So I was help him, and then the guy he promised me, he help me as well...to go somewhere to get safe" (Naz, male, Somali refugee, 19-21, Glasgow).

The everyday memories of family are present in Naz's reflections; he recalls working alongside his father and the guidance and support given in anticipation of crisis. He talks about the extra-familial network of family friends and places of worship as trusted sites of security showing the 'strength of weak ties' (Granovetter, 1973 cited in Hopkins and Hill, 2008). By contrast, many of the unfamiliar and 'official' networks of support were perceived to be less trustworthy leading to a more untenable sense of security. Later in the interview, Naz explained that the journey to the UK and the loss of family had deeply affected his mental health. Travelling to the UK by 'truck', exploited by 'agents' and left on the streets upon arrival, Naz says 'I risk a lot, my life, to come here'. However, he referred to the processing of his asylum claim by the Home Office as one of the major challenges to achieving a secure life, culminating in thoughts of suicide.

"they told me everything, they help me, they give you, and then I waiting for long time. And then no, I like, you don't have power to, like, to force them and then to give you. So, the time I was, like, I decided a lot of things, like, to kill myself because I was staying in the flat, and then myself, nobody there"

The unwieldy infrastructure surrounding the process of asylum renders Naz powerless, suspended between settlements and familiar attachments and he expresses a profound sense of ontological insecurity and loneliness. He is not deemed a legal person by those governing migration, he is 'waiting' as a 'biopolitical' subject whose legitimacy and value is This is the pre-proofed 'accepted' version of the paper now published in Geopolitics. 
directed and governed by the state (Agamben, 1998). Crawley (2010) has discussed the lack of humanity in asylum interviews conducted with unaccompanied minors applying for refugee status in the UK and calls for a more child-focused asylum system. Furthermore, although the timescale varies, there is evidence that some unaccompanied children have to wait for months or even years to learn about the final outcome of their asylum applications in the UK extending their sense of 'waiting' and questioning their sense of being and belonging (Conlan, 2011).

Similarly, for Sahra, another Somali refugee living in Glasgow, negotiating access to education and housing without the support of family was a source of extreme stress and upset, in spite of support via a state-sponsored guardianship programme. Having explained her circumstances to officials, agents, support workers and researchers Sahra says 'I am tired to tell everybody about my story'. The continual requirement to justify herself as legitimate and relevant is a source of weary frustration, and while she is positive about Scotland and the guardianship programme she is supported by, there are ongoing anxieties:

"I want to have confidence but...sometime I am going to ask in the [housing] office 'I want to do this' or 'I have this letter from... this office, can you explain [to] me'. Just people they don't care about you... [they say] 'just phone this number'. For me, I feel sad because ... this is your job, you must help me yeah. Sometimes I say, [is it] because I am wearing this scarf? [Is it] because [of] my colour? ...I want to do [it] myself, but it is hard for me... I am alone here. At least [when] I live with my mum. My mum she help me ... Yeah. I don't have anybody just to help me, just guardianship. Maybe after two years or three years when I am finished to work with guardianship, who will help me?" (Sahra, female, Somali refugee, 19-21, Glasgow)

Sahra refers to her family when revealing her anxiety about the future and the everyday challenges she experiences. The feeling of being alone knocks her confidence despite networks of social and institutional support, she 'misses' her family and her mum. As networks of support vacillate, emotional and material insecurity beckon and reveal the inadequacy of asylum infrastructures in the UK. As the system works to differentiate the 'foreign' from the 'domestic', individuals seeking asylum are straddled between spaces of belonging. Yet, as Williams (2014) suggests asylum 'fundamentally relies upon exclusion' because it operates within the structure of the territorial nation state (cited in Loyd, 2015). Asylum seekers and refugees are thus permanently deportable and subject to processes of exclusion at the border and within post-colonial spaces of dispersal neighbourhoods. As Loyd (2015:4) argues, 'it is not only at the boundary of a national territory where friendThis is the pre-proofed 'accepted' version of the paper now published in Geopolitics. 
enemy relations result in the militarized regulation of mobility, but also domestically, within spaces already differentiated by race, class, and differential citizenship'. For Sahra, the combination of anticipated racial or religious discrimination intensify her isolation, making it more difficult to negotiate a secure life in the UK without the traditional support of family networks.

For both Sahra and Naz, re-building the familiar happened through establishing friendships and building makeshift families in temporary accommodation when they were dispersed to Glasgow. While the hostel is a holding space as asylum claims are processed, it is also a site of sociality as young people make friends and build communities, as Naz reflects here.

"I made different friends because the time I was living in hostel I was different friends that was Chinese, Vietnam, Afghanistan, Iraq. And there was good people because we are all refugees and then we come here for help. So we stay like a family, yeah...Yeah, that's like family. If someone call someone, if he come and saw you he ask you what's the problem, you need some help, just call me, or tell me anything you want. Yeah, we stay like family"

Naz says the important friendships made in spaces of refuge become 'like family'. As Brun and Fabos (2015) note, for many displaced persons making home involves negotiating social relations in place. Rather than view refugees as 'passive victims' Brun and Fabos discuss the 'agency-in-waiting' of refugees as they negotiate the uncertainties of temporary homes because even temporary placements are social spaces of intersubjective encounter. The extract from Naz also shows that within the hostel family-making strategies are international, diverse and multicultural, countering normative assumptions that migrants form translocal attachments along ethno-national lines in migration destinations (Werbner, 2005). The friendship group he has established is embedded in the wider geopolitics of war, displacement and the 'protracted' governance of asylum. The provision and securitization of asylum accommodation in the UK is very contentious (Darling, 2016). One of the challenges is where to accommodate children over the age of 16 who cannot be housed in residential care but are placed in a very vulnerable position is accommodated in 'adult' provision, such as in homeless shelters. The security of accommodation where relationships can be established with social care workers and other young people, coupled with the provision of a 'guardian' (Crawley and Kohli, 2013) are significant, however, in enabling unaccompanied minors to establish a sense of belonging and the creation of new networks of support in place of their family.

This is the pre-proofed 'accepted' version of the paper now published in Geopolitics. 


\section{Conclusion}

This paper has argued that the domestic realm of the family is an important site of geopolitics. Drawing on interviews with ethnic and religious minority young people in Scotland, the paper contributes to a growing body of work aimed at challenging dominant discourses in the geopolitics of security that focus singularly on the international. Whilst feminist geopolitics makes this challenge clear, this has tended to emphasise the significance of embodied, emotional and intimate geopolitics. It is important to analyse the sites where geopolitics is felt, negotiated, mediated and interpreted that are both within and beyond the body - in homes (Brickell, 2012), families (Harker, 2012) and schools (Benwell, 2014). We have focused on the family as a site of (in)security where geopolitics is scripted, resisted and actioned in diverse ways. Immediate and extended familial relationships are significant in shaping perceptions and experiences of the insecurities produced by geopolitics and influence youth resistance and engagements that shape geopolitics. Furthermore, in circumstances where immediate family is absent, other relationships (e.g. friendships and guardians) are key to young people's sense of being and belonging in place.

A key aim of the paper is to advance the concept of OS as a valuable analytic to explore the psycho-social domain as a key part of the emotional geopolitics of security. We have used the family to illustrate the relational, psycho social dynamics that shape feelings of ontological (in)security among young people. We have made two key arguments in defence of this approach. First, it enables us to understand how emotional, social and political life are connected through a focus on relational, psycho-social processes in the 'home' and 'family'. Specifically, we have discussed how state regimes of migration, asylum and integration that dehumanize and depersonalize work against OS within and between families. Ehrkamp (2016:4) suggests that the securitization and management of migration has meant that 'security logics are undermining human rights commitments and rationales'. The apparent contradiction between human rights and security demonstrates this logic is partial and incomplete: it overlooks the intimate and ontological (in)securities of individuals engaged in processes of migration and asylum as well as those securitized in everyday landscapes by virtue of their race or religion. The current policing of the US-Mexico border and brutal family separation policies and practices by the US government and governments across the EU are stark examples of an increasingly vicious biopolitics of the border. In this paper we highlight the interconnections between such international/transnational geopolitical scenarios, the OS of individual young people and the meso-scale of the family. As such as advocate a relational and multiscalar analysis of security and migration. This maps onto and extends work on intimacy-geopolitics and the 'geosocial', enabling and invigorating engagements This is the pre-proofed 'accepted' version of the paper now published in Geopolitics. 
between critical and feminist geopolitics and those working on the sociology and anthropology of the family.

Our second argument is methodological. To analyse OS requires in-depth focus on individual narratives of personhood which also means viewing young people as having agency. Young people talk about their anxieties, fears and vulnerabilities in a range of ways and we have taken care to ground ideas about insecurity in youth-centred biographies. This is not beyond representation and there are further ethical issues to discuss in how we ethically and hopefully analyse young people's psycho-social lives. This paper has shown, however, that such an approach can reveal the often emotional, resilient and sometimes contradictory experience of security in the family and how young people negotiate and incorporate the political into their everyday, emotional lives. As Thien (2005) has argued, the focus on an emotional subject 'offers an intersubjective means to negotiating our place in the world, co-produced in cultural discourses of emotion as well as through psycho-social narratives'. Such an approach is attendant to the relational, intersubjective and in-process nature of human security. As regional and national securities tighten across the globe with profoundly dehumanizing effects, understanding the emotional and personal challenges and responses of families and individuals is vital to make visible the relational and psycho-social dynamics of protection, resistance and solidarity.

\section{REFERENCES}

Abu-Lughod I (2002) 'Do Muslim women really need saving? Anthropological reflections on cultural relativism and its others', American Anthropologist, 104(3): 783-790.

Afshar H, Aitken R, \& Myfanway F (2005), 'Feminisms, Islamophobia and identities', Political Studies, 53: 262-283.

Agamben G (1998) Homo Sacer: Soveriegn Power and Bare Life. Stanford: Stanford University Press

Alexander C, Edwards R \& Temple B (2007) Contesting Cultural Communities: Language, Ethnicity and Citizenship in Britain. Journal of Ethnic and Migration Studies 33(5):738-800

Beck U \& Beck-Gernsheim E (2002) Individualization. London: Sage

This is the pre-proofed 'accepted' version of the paper now published in Geopolitics. 
Benwell M (2014) From the banal to the blatant: Expressions of nationalism in secondary schools in Argentina and the Falkland Islands. Geoforum 52:51-60

Benwell M and Hopkins P (2016) Children, Young People and Critical Geopolitics. Farnham, Ashgate

Beier JM (2015) Children, childhoods, and security studies: an introduction, Critical Studies on Security, 3(1): 1-13

Bigo D (2002) Security and immigration: Toward a critique of the governmentality of unease. Alternatives: Global, Local, Political 27: 63-92.

Blunt A and Dowling R (2006) Home. Oxon: Routledge

Booth K (2007) Theory of World Security. Cambridge: Cambridge University Press.

Bourne M (2014) Understanding Security. New York, Palgrave Macmillan

Brickell K (2012) Geopolitics of Home. Geography Compass 6(10):575-588

Brickell K \& Datta A (2011) (eds) Translocal Geographies Spaces, Places, Connections. Farnham: Ashgate

Brun C \& Fábos A (2015) Making homes in limbo? A conceptual framework. Refuge 31: 517.

Caluya G (2010) Domestic belongings: intimate security and the racial politics of scale. Emotion, Space and Society 4:1-8

Cieslik M and Pollock G (eds) (2002) Young People in Risk Society: The Restructuring of Youth Identities and Transitions in Late Modernity. Hampshire, UK: Ashgate.

Conlon D (2011) Waiting: Feminist perspectives on the spacings/timings of migrant (im)mobility. Gender, Place and Culture 18: 353-360.

Conradson D \& McKay D (2007). Translocal Subjectivities: Mobility, Connection, Emotion.469 Mobilities 2(2):167-174

This is the pre-proofed 'accepted' version of the paper now published in Geopolitics. 
Cowen D and Story B (2013) Intimacy and the everyday Dodds K Kuus M and Sharp J (eds) The Ashgate Companion to Critical Geopolitics Ashgate, Farnham 341-358.

Crawley H (2010) 'No one gives you a chance to say what you are thinking': finding space for children's agency in the UK asylum system. Area 42(2), 162-169.

Crawley H \& Kohli R (2013) 'She endures with me. an evaluation of the Scottish Guardianship Service Pilot'. Edinburgh: Scottish Government.

Darling J (2016) Forced migration and the city: Irregularity, informality, and the politics of presence. Progress in Human Geography. DOI: 10.1177/0309132516629004.

Din I (2016) The New British: The Impact of Culture and Community on Young Pakistanis. Abingdon: Ashgate

Dowler L and Sharp J (2001) A feminist geopolitics? Space and Polity 5(3) 165-176.

Dwyer C (2000) Negotiating diasporic identities: Young British South Asian Muslim women. Women's Studies International Forum, 23: 475-86.

Ehrkamp P (2013) 'I've had it with them!' Younger migrant women's spatial practices of conformity and resistance. Gender, Place and Culture 20(1):19-36

Ehrkamp P (2016) Geographies of Migration I: Refugees. Progress in Human Geography. DOI: 10.1177/0309132516663061

Enloe C (1990) Bananas, Beaches, and Bases: Making Feminist Sense of International Politics. Berkeley, CA: University of California Press.

Finch J and Mason J (1993) Negotiating Family Responsibilities. London: Routledge.

Fregonese S (2017) Affective atmospheres, urban geopolitics and conflict (de)escalation in Beirut. Political Geography 61:1-10

Giddens A (1991) Modernity and Self-Identity. Stanford, CA: Stanford University Press

This is the pre-proofed 'accepted' version of the paper now published in Geopolitics. 
Gökarıksel B (2009) Beyond the officially sacred: religion, secularism, and the body in the production of subjectivity. Social \& Cultural Geography 10 (6): 657-674

Harker C (2012) Precariousness, precarity, and family: notes from Palestine. Environment and Planning A 44:849-865

Holloway SL, Hubbard P, Jons H \& Pimlott-Wilson H (2010) Geographies of education and the significance of children, youth and families. Progress in Human Geography 34(5):583600

Hopkins P \& Hill M (2008) Pre-flight experiences and migration stories: the accounts of unaccompanied asylum-seeking children. Children's Geographies, 6(3): 257-268.

Hopkins P \& Hill M (2010) The needs and strengths of unaccompanied asylum-seeking children and young people in Scotland. Child and Family Social Work, 15(4): 399-408.

Hopkins P, Olson E, Pain R, \& Vincett G (2011) Mapping intergenerationalities: the formation of youthful religiosities. Transactions of the Institute of British Geographers, 36(2) 314-327

Hopkins P, Olson E, Baillie Smith M \& Laurie N (2015) Transitions to religious adulthood: relational geographies of youth, religion and international volunteering. Transactions of the Institute of British Geographers, 40(3) 387-398.

Hörschelmann K (2008) Populating the landscapes of critical geopolitics - young people's responses to the war in Iraq. Political Geography 27(5): 587-609.

Hörschelmann K and Reich E (2017) Entangled (In)Securities: Sketching the Scope of Geosocial Approaches for Understanding "Webs of (In)Security”. Geopolitics 22(1):73-90

Hyndman J (2001) Towards a feminist geopolitics. The Canadian Geographer, 2: 210-222

Hyndman J (2004) Mind the gap: bridging feminist and political geography through geopolitics. Political Geography 23 307-322.

Hyndman J (2010) Introduction: The feminist politics of refugee migration. Gender, Place and Culture 17: 453-459.

This is the pre-proofed 'accepted' version of the paper now published in Geopolitics. 
Jamieson L (1998) Intimacy: Personal Relationships in Modern Societies. Cambridge: Polity Press.

Kapur R (2002) Un-veiling women's rights in the "war on terrorism" Duke Journal of Gender and Law, 9: 211-225.

Katz C (2004) Growing up global: Economic restructuring and children's everyday lives, Minneapolis: MN University of Minnesota Press.

Kinnvall C (2004). Globalization and religious nationalism: self, identity, and the search for ontological security. Political Psychology, 25(5), 741-767

Kohli RKS (2011) Working to ensure safety, belonging and success for unaccompanied asylum-seeking children. Child Abuse Review 5: 311-323.

Koopman S (2011) Alter-geopolitics: other securities are happening. Geoforum 42 274-284

Laing RD (1960) The Divided Self. London, Tavistock Publications

Laing RD (1969) The Politics of the Family. London: CBC Enterprises

Laketa S (2016) Geopolitics of Affect and Emotions in a Post-Conflict City. Geopolitics 21(3): 661-685

Levitt P \& Waters M (2002) (Eds) The Changing Face of Home: The Transnational Lives of the Second Generation. New York: Russell Sage Foundation.

Loyd JM (2015) Carceral citizenship in an age of global apartheid. Occasion 8: 1-15

McGeachan C (2014) 'Worlding' Psychoanalytic Insights: Unpicking R.D. Laing's Geographies. In: Kingsbury P \& Pile S (2014) Psychoanalytic Geographies. Farnham, Ashgate

Mitchell K \& Kallio KP (2017) Spaces of the Geosocial: Exploring Transnational Topologies. Geopolitics 22(1):1-14

This is the pre-proofed 'accepted' version of the paper now published in Geopolitics. 
Morgan DHJ (2015) The Family, Politics and Social Theory. London: Routledge (first published 1975)

Mountz A, Coddington K, Catania RT, \& Loyd JM (2013) Conceptualizing detention: Mobility, containment, bordering, and exclusion. Progress in Human Geography 37(4): 522-541.

Nagar R (1998) Communal discourses, marriage, and the politics of gendered social boundaries among south Asian immigrants in Tanzania. Gender, Place and Culture, 5(2): 117-139.

Neocleous M (2008) Critique of Security. Montreal, QC: McGill-Queen's University Press.

Ni Raghallaigh M and Gilligan R (2010) Active survival in the lives of unaccompanied minors: coping strategies, resilience, and the relevance of religion. Child and Family Social Work, 15(2): 226-237.

Ojeda D (2013) War and tourism: the banal geographies of security in Colombia's 'Retaking'. Geoforum 18(4):759-778

Pain R (2009) Globalized fear? Towards an emotional geopolitics, Progress in Human Geography 33(4) 466-486

Pain R, Panelli R, Kindon S \& Little J (2010) Moments in everyday/distant geopolitics: young people's fears and hopes Geoforum 41 972-982.

Pain R and Smith S (eds) (2008) Fear: Critical Geopolitics and Everyday Life. Abingdon: Ashgate

Pain R and Staeheli L (2014) Introduction: Intimacy-Geopolitics. Area, 46(4):344-347

Porteous D and Smith S (2001) Domicide: The Global Destruction of Home. Montreal and Kingston: McGill Queen's University Press

Pratt G (2012) Families Apart: Migrant Mothers and the Conflicts of Labor and Love Minneapolis: University of Minnesota Press

This is the pre-proofed 'accepted' version of the paper now published in Geopolitics. 
Reynolds T \& Zontini E (2016) Transnational and diasporic youth identities: exploring conceptual themes and future research agendas, Identities, 23(4): 379-391.

Richardson MJ (2015) Embodied intergenerationality: family position, place and masculinity. Gender, Place and Culture 22(2), 157-171.

Sanghera G \& Thaiper-Bjorkert S (2012) “"Let's Talk About...Men” - Young British Pakistani Muslim Women's Narratives about Co-Ethnic Men in "Postcolonial" Bradford', Interventions International Journal of Postcolonial Studies, 14(4): 591-612.

Sanghera G \& Thaiper-Bjorkert S (2017) 'Transnationalism, social capital and gender young Pakistani Muslim women in Bradford, UK', Migration Letters, 14:1, pp.88-100.

Scottish Government, (2017) New Scots Refugee Integration Strategy 2018-22. Directorate for Communities and Third Sector, Available at: https://beta.gov.scot/publications/new-scotsrefugee-integration-strategy-2018-2022/ [Accessed:18/6/18]

Secor A (2001) Towards a feminist counter-geopolitics: gender, space and Islamist politics in Istanbul Space and Polity 5(3): 191-211

Secor A (2002) The veil and urban space in Istanbul: Women's dress, mobility and Islamic knowledge. Gender, Place and Culture, 9: 5-22.

Sharp J (2013) Geopolitics at the margins? Reconsidering genealogies of critical geopolitics. Political Geography, 37: 20-29

Shepherd L (ed.) (2013) Critical Approaches to Security: An Introduction to Theories and Methods. London, Routledge.

Singh J (2015) 'Family values: The Impact of Family Background on the Religious Lives of Young British Sikhs', K. A. Jacobsen \& K. Myrvold (eds) Young Sikhs in a Global WorldNegotiating Traditions, Identities and Authorities, Farnham: Ashgate, pp. 15-34.

Steele B (2008). Ontological Security in International Relations: Self-identity and the IR State. New York, Routledge

This is the pre-proofed 'accepted' version of the paper now published in Geopolitics. 
Thien D (2005) After or beyond feeling? A consideration of affect and emotion in geography. Area 37(4): 450-54

Valentine G (2008) The ties that bind: towards geographies of intimacy. Geography Compass 2(6):2097-2110

Vanderbeck RM (2007) Intergenerational geographies: age, relations, segregation and reengagements. Geography Compass 2:200-221

Vertovec S (2004). Trends and Impacts of Migrant Transnationalism. Oxford: Centre on Migration, Policy and Society Working Paper No. 3, University of Oxford.

Watson A (2006) 'Children and International Relations: A New Site of Knowledge? Review of International Studies, 32: 237-250.

Werbner P (2005) 'The translocation of culture: "community cohesion" and the force of multiculturalism in history', Sociological Review, 53:4, pp.745-768.

Wibben ATR (2011) Feminist Security Studies: A Narrative Approach. Abingdon, Routledge Williams F (2004) Rethinking Families. London, Calouste Gulbenkian Foundation Williams J \& Massaro J (2013) Feminist Geopolitics: Unpacking (In)Security, Animating Social Change. Geopolitics 18(4): 751-758

This is the pre-proofed 'accepted' version of the paper now published in Geopolitics. 